\title{
POCZĄTKI CHRZEŚCIJAŃSKIEGO SZKOLNICTWA W EUROPIE ZACHODNIEJ
}

Po upadku państwa rzymskiego wykształcone warstwy ludzi europejskiego wczesnego średniowiecza zaczęły pracować nad wykształceniem własnego modelu szkolnictwa. Na miejsce starożytnego, ukształtowanego jeszcze w Grecji, ideału wychowania wszechstronnego i antropocentrycznego, w chrześcijaństwie łacińskim pojawiła się teocentryczna wiara chrześcijan dążących głównie do wykształcenia o charakterze elitarnym. Szkolnictwo pozostawało w zasadzie w rękach duchowieństwa. Zakładanie szkół przy katedrach sięga czasów patrystycznych. We wczesnym średniowieczu szkoły elementarnego nauczania zakładano głównie przy klasztorach. Rzadko czyniono to na dworach. Ówczesne szkoły kładły nacisk na wykształcenie religijne i wykształcenie chrześcijańskie. W zasadzie przygotowywały do studiów biblijnych.

Podstawę do powstania kultury umysłowej w zachodniej Europie dało poznanie ocalałych dzieł starożytnej Grecji i Rzymu. Pojawiła się ona najpierw w pismach patrystycznych. W przekazaniu tak zinterpretowanego dorobku niebagatelną rolę odegrał Augustyn, Boecjusz, Kasjodor, Marcjan Capella, Izydor ze Sewilli, Dionizy Pseudo-Areopagita, Alkuin, Hraban Maur i Jan Eriugena ze Szkocji.

Wiek V określany jako barbarzyński stanowi cezurę nie tylko między antykiem i średniowieczem, lecz także między starożytnymi prądami filozoficznymi z jednej strony i między myślą chrześcijańską uksztaltowaną w okresie patrystyki i we wczesnym średniowieczu z drugiej strony. Spośród tych pierwszych poprzez Senekę, Epiketa, Warona a zwłaszcza Cycerona oddziałała stoicka retoryka i etyka. Sporo zamieszania spowodował ruch religijny propagujący gnostycyzm ze swoim radykalnym dualizmem ducha i materii. $\mathrm{Z}$ niego wyłonił się manicheizm $\mathrm{z}$ doktryną o królestwach światła $\mathrm{i}$ ciemności. Żyd Filon z Aleksandrii (ok. 13 przed Chr. - 50 po Chr.) w komentarzu do Ksiegi Rodzaju i w innych pismach przygotował grunt do połączenia filozofii helenistycznej z Biblia.

W V wieku skończył się pierwszy okres chrystianizacji świata pogańskiego zwany patrystyką. Jako ojcowie wiary nabrali oni w późniejszych czasach niezwykłego autorytetu w średniowiecznej myśli chrześcijańskiej nie tylko teologicznej, lecz także filozoficznej. Ta ostatnia nie była wiedzą samo- 
dzielną, lecz mieściła się w ramach pierwszej. Za pierwszego z filozofów chrześcijańskich uchodzi Justyn († ok. 165), według którego filozofia wiedzie do Boga. Klemens z Aleksandrii ( $\dagger$ przed 215) uważał, że filozofia prowadzi do cnoty i prawdy, w której poznaniu wiara stoi wyżej od rozumu. Przez to stworzył podstawy do utworzenia samodzielnej nauki chrześcijańskiej. Przez spekulatywno-syntetyczne ujęcie wiary objawionej Orygenes (ok. 185-254) stał się nie tylko ważnym teologiem Kościoła greckiego, lecz także przysłużył się filozofii.

Myśl chrześcijańska i wiedza o Objawieniu, według którego osobowy i trójjedyny Bóg stanowi początek, różniła się już u swojego zarania od starożytnych prądów filozoficznych, w których bezosobowy bóg jako trwała zasada bytu pojawia się dopiero na końcu rozważań nad wszechświatem. Przed myślicielami chrześcijańskimi stanęły większe zadania, gdy przyszło jej traktować o żywym Bogu jako stwórcy, o człowieku jako duchu w ciele i o stworzonym z niczego świecie. Epokowy przełom zaczął się u schyłku antyku i u początków kształtowania się patrystyki tak wschodniej jak i zachodniej. Dokonywał się jednak powoli. Do chrześcijańskiej wiedzy istotny wkład wnieśli wielcy myśliciele - filozofowie i teolodzy w jednej osobie.

Jednym $\mathrm{z}$ wielkich ojców Kościoła na Zachodzie był św. A u g u s t y n (354-430), biskup Hippony. Mimo że żył w imperium rzymskim, działał w ukształtowanym w poważnej mierze przez neoplatonizm, stoicyzm i epikureizm duchowym świecie hellenistycznym. Znał pisma Cycerona i Plotyna oraz Kategorie Arystotelesa. Chociaż chciał być tylko teologiem, stał się też filozofem. Mimo że nie opracował koherentnego systemu w tych dziedzinach wiedzy, wpływ jego myśli był tak wielki, że stwożył podwaliny pod chrześcijańskie średniowiecze na Zachodzie aż do XII wieku. Dla niego filozofia była poszukiwaniem prawdziwej mądrości nadprzyrodzonej, zawartej w Objawieniu. Mimo że nie opracował zwartej i szczegółowej orientacji, jego doktryna stanowi szczytowy punkt filozofii patrystycznej ${ }^{1}$. Przez podporządkowanie jej Objawieniu przełamał utrzymującą się w pismach ojców Kościoła niechęć do starożytnej filozofii pojętej jako czysto rozumowe rozważania o rzeczach ludzkich i boskich. Wewnętrznie związał filozofię ze światopoglądem, który jest oparty na sławnej dewizie: Credo ut intelligam ${ }^{2}$. U Augustyna nie da rozdzielić się wiary i wiedzy. Stąd też teologia i filozofia stanowią jedność. Przyjęcie boskiego Objawienia przez wiarę bowiem ułatwia człowiekowi poznanie Boga: „Filozofia, która chce być prawdziwą przyjaciółką mądrości, powinna wychodzić $\mathrm{z}$ wiary, której będzie zrozumieniem. Religia, która chce być tak doskonała, jak to jest możliwe, powinna dążý do zrozumienia zaczynając od wiary. Tak rozumiana prawdziwa religia jest jednym $\mathrm{z}$ prawdziwa filozofią"3. Najbardziej uwidocznil się u niego wpływ neoplatonizmu. Przed-

${ }^{1}$ Ph. B ö h n e r, E. G il s o n, Historia filozofii chrześcijańskiej. Od Justyna do Mikotaja Kuzańczyka, przekł. S. Stoma, Warszawa 1962, s. 158.

${ }^{2}$ E. G i l s o n, Wprowadzenie do nauki świętego Augustyna, przekł. Z. Jakimiak, Warszawa 1953, s. 12.

${ }^{3}$ Cyt. tamże, s. 42. 
stawiony przez Augustyna wszechświat jest zorganizowany na wzór idei Bożych. Przez to stworzył on c h r ze ś c i j a ń s k i p la t o n i z m, którego charakterystyczną cechą jest egzemplaryzm, iluminizm, woluntaryzm, interioryzm, spirytualizm i dualizm antropologiczny. Do tego dochodziła jeszcze schrystianizowana przez niego stoicka teoria tzw. zarodków rozumowych ( $\mathrm{ra}$ tiones seminales). W kształtowaniu średniowiecznej nauki niemałą rolę odegrało także podane przez Augustyna w De doctrina christiana stwierdzenie, że nauka odnosi się albo do rzeczy, albo do znaków. Na gruncie samoświadomości przezwyciężył on sceptycyzm: Jeżeli bowiem mylę się, to jestem (Si enim fallor, sum). Prawda znajduje się we wnętrzu człowieka (Noli foras ire, in te ipsum redi). W polądach na stworzenie świata Augustyn opowiedział się przeciw pogańskiej tradycji platońskiej i plotyńskiej i przyjął chrześcijański opis stworzenia świata z niczego podany w Księdze Rodzaju. Przy tym platońskiemu światu idei dał interpretację chrześcijańską przez umieszczenie idei w umyśle Boga, którego w De Trinitale libri $X V$ określił jako prostą substancje (substantia), niezmienną istotę (essentia) i samoistne istnienie (esse). Mimo że człowiek stanowi jedność ciała i substancjalnej, niematerialnej i nieśmiertelnej duszy, Augustyn nie zdołał pokonać neoplatońskiego dualizmu ontycznego w samym stworzeniu. Tak też było w etyce. Każdy człowiek dąży do szczęścia (beatitudo). Z tego względu uprawia się także filozofię (Nulla est homini causa philosophandi, nisi ut beatus sit). Śmiertelność człowieka sprawia, że w doczesnym życiu nie może on być w pełni szczęśliwy".

W De doctrina christiana Augustyn przestawił także swoje wyobrażenia odnośnie szkolnictwa w chrześcijańskim średniowieczu Europy zachodnej. Miało ono koncentrować się wokół Pisma św. Nauki świeckie, jak umiejętności wyzwolone (artes liberales) miały służyć tylko do jego lepszego objaśnienia.

Po podziale imperium rzymskiego w 395 roku na wschodnie i zachodnie a u g u sty n izm, w którym nie ma wyraźnego rozgraniczenia filozofii i teologii, znalazł wielu zwolenników już we wczesnym średniowieczu na Zachodzie. Do nich należeli m. in. Kasjodor, papież Grzegorz Wielki, Izydor z Sewili i Alkuin. Dzięki zaleceniom Augustyna, ażeby w klasztorach tworzono księgozbiory i uprawiano wspólną lekturę jako podstawa do rozmyślań duchowych $^{5}$, nastapił przełom w zakresie pedagogiki zachodniej. Zasługa Augustyna z Hippony jest także wprowadzenie do niej umiejętności wyzwolonych, które swoimi korzeniami sięgały wytworzonego w Grecji ${ }^{6}$, przyjętego przez Rzymian i rozpowszechnionego w średniowieczu systemu wyższego, ogólne-

${ }^{4}$ „Omnes homines quamdiu mortales sunt, etiam miseri sint necesse est”; [A u g u st in u s 1, De civitate Dei, wyd. B. D o $\mathrm{m} \mathrm{h}$ a r t, A. K a I b, Tumhout 1955, IX, $15 \mathrm{cf}$. G. W i e lan d, Happiness: the Perfection of Man, [w:] The Cambridge History of Later Medieval Philosophy: from the Rediscovery of Aristote to the Disintegration of Scholasticism 1100-1600, wyd. N. Kretzmann, A. Kenny, J. Pinborg, Cambridge 1982, s. 673.

${ }^{5} \mathrm{M}$. M e 11 e t, L'itinéraire et l'idéal monastique de saint Augustin, Paris 1934, s. $19 \mathrm{n}$.

${ }^{6}$ Ars pochodzi od $\tau \varepsilon \phi v \eta$, disciplina, doctrina. Pierwotnie oznaczała umiejętność, której można nauczyć się tecznicznie lub ręcznie. F. H. R ob in g, Ars, [w:] Historisches Wörterbuch der Rhetorik. I: $A-B i b$, hrsg. v. G. Ueding, pod red. G. Kalivoda, F. H. Robing, Tübingen 1992, kol. 1009. 
go kształcenia. W tym bowiem czasie nie stanowiły one jeszcze przedmiotu nauczania samego w sobie. Ich liczba była zmienna. Dzięki Warronowi i Augustynowi przyjęto ostatecznie siedem (septem artes liberales). W takiej liczbie weszły one do łacińskojęzycznego Zachodu jako system wykształcenia i wiedzy. Ich pielęgnowaniem i rozpowszechnianiem zajął się Kościół.

U Boecjusza występuje już podział siedmiu umiejętności na trivium (gramatyka, retoryka, dialektyka) ${ }^{7}$ i quadrivium (arytmetyka, geometria, teoria muzyki i astronomia) ${ }^{8}$. Znalazł on swoje uzasadnienie w Piśmie św.: „Die Weisheit hat ihr Haus gebaut, ihre sieben Säulen behauen"9. W powszechne użycie wszedł on dopiero w XI wieku. Upowszechniano pogląd: Grammatica loquitur, dialectica vera docet, rhetorica verba ministrat, musica canit, arithmetica numerat, geometria ponderat, astronomia colit astra. Mimo swojego charakteru świeckiego (artes saeculares) Augustyn, Kajodor, Izydor z Sewilli, Beda Czcigodny, Alkuin, Raban Maur, szkoła w Chartres, Hugon od Św. Wiktora i Jan z Salisbury przyczynili się do uznania ich jako niezbędnego przygotowania do studium Pisma św., które samo dotąd stanowiło podstawę wykształcenia. Miały się stać pomocą do lepszego jego zrozumienia ${ }^{10}$. To przedsiewzięcie Augustyn zdołał zrealizować tylko w dziedzinie gramatyki i częściowo w zakresie muzyki. Od tego czasu we wczesnym średniowieczu będą pojawiać się próby wprowadzenia antycznego kanonu nauczania na obszarze chrześcijańskiego Zachodu.

Augustyn oddziałał także jako myśliciel. W późniejszych czasach jego myśl urosła do potężnego prądu umysłowego. Zwolennikami augustynizmu stali się m. in. Anzelm z Canterbury, Piotr Abelard, Hugon ze Św. Wiktora i Piotr z Lombardii. W XIII wieku Bonawentura pogłębił znacznie ten prąd umysłowy. Do recepcji filozoficznych pism Arystotelesa (384-322 przed Chr.) subiektywizm augustyński nie miał konkurentów. Chociaż ma za sobą już piętnaście wieków, to jego duch znajduje nadal zwolenników i sympatyków ${ }^{11}$.

Po wielkim upadku kultury umysłowej w tym regionie Europy podtrzymywaniem życia umysłowego zajął się $\mathrm{m}$. in. afrykański pisarz łaciński $\mathrm{M}$ a r c j a n $\mathrm{C}$ a p e 11 a. Uwzględnił on wszystkie artes liberales. Dzięki niemu wszedł w życie kanon septem artes liberales. Jest autorem napisanego pomiędzy 417 a 427 rokiem ${ }^{12}$ alegorycznego traktatu De nuptiis Mercurii et Philologiae ${ }^{13}$, który w wiekach średnich stał się wzorem i popularnym pod-

${ }^{7} \mathrm{~W}$ IX w. te trzy sztuki nazwano artes sermocinales.

${ }^{8} \mathrm{~W}$. B e r g m a n n, Innovationen im Quadrivium des 10. und 11. Jahrhunderts. Studien zur Einführung von Astrolab und Abakus im lateinischen Mittelalter, Stuttgart 1985, s. 15.

${ }^{9}$ Buch der Sprichwörter, 9, 1.

${ }^{10}$ M. M a r k ow s k i, Artes liberales, [w:] Encyklopedia katolicka, t. 1, Lublin 1985, kol. 956.

${ }^{11}$ S. K ow a lc zyk, Bóg jako najwyższe dobro, [w:] Z filozofii św. Augustyna i św. Bonawentury, Opera philosophorum medii aevi. Textus et studia, t. 3, red. B. Bejze, Warszawa 1980, s. 31.

${ }^{12}$ F. S c h a l k, Zur Entwicklung der artes in Frankreich und Italien, [w:] Artes liberales. Von der antiken Bildung zur Wissenschaft des Mittelalters, wyd. J. Koch, 1959, reprint 1976, s. 143.

${ }^{13}$ H. B a c ke s, Martianus Capella, [w:] Lexikon des Mittelalters, t. 6, München, Zürich 1992, kol. 338-339. 
ręcznikiem umiejętności wyzwolonych. W wyniku tego za Zachodzie pojawiła się wiedza świecka.

$\mathrm{Na}$ tym odcinku jeszcze dalej posuneła się translatorska i komentatorska działalność B o e c j u s z a (Anicius Manlius Torquatus Severinus Boethius, ok. 480-524) ${ }^{14}$, potomka senatorskiego i chrześcijańskiego rodu Anicjuszów i ucznia Akademii Platońskiej. Stał się pośrednikiem między grecką myślą antyczną i wczesnego średniowiecza. Usiłował pogodzić poglądy filozoficzne Platona i Arystotelesa. Przebywając jako Rzymianin na germańskim dworze króla ariańskich Gotów, Teodoryka († 526), starał się ratować duchowe dziedzictwo antyku. W pierwszym rzędzie dotyczyło to siedmiu umiejętności wyzwolonych. Mając lat dwadzieścia zaczął pisać swoje pierwsze dzieła. W wieku dwudziestu pięciu lat komentował pisma Arystotelesa. Dzięki dokonanym przez Boecjusza przekładom i komentarzom poznano bowiem na Zachodzie logiczne dzieła Arystotelesa. W pismach Boecjusza były także obecne treści platońskie. Chociaż był neoplatonikiem, starał się jednak łączyć filozofię platońską $\mathrm{i}$ arystotelesowską, a nawet wykazywać ich jednomyślność w niektórych poglądach filozoficznych. W następstwie tych zabiegów już około 500 roku przedstawił Arystotelesa jako platonika. Około 510 przełożył na język łaciński Kategorie i Hermeneutykę Arystotelesa. Stworzył łacińską terminologię, która weszła do filozofii średniowiecznej. Od niego pochodzi też określenie quadrivium, które dotyczyło głównie wiedzy o liczbach. $Z$ tej racji należało ono do kosmologii ${ }^{15}$. Nie napisał on wprawdzie encyklopedii obejmującej wszystkie sztuki wyzwolone, ale jego dzieła De institutione musica ${ }^{16}, D e$ institutione arithmetica i De geometria stały się przez długi czas podstawowymi podręcznikami o muzyce, arytmetyce i geometrii Euklidesa ${ }^{17}$. Dzieło Boecjusza De Trinitate triumfy popularności święciło w XII wieku w szkole w Chartres. Odczekując w więzieniu na śmierć, napisał w latach 523-524 dzieło swego życia, mianowicie książkę o pociechach, jakie daje filozofia. Przedstawiona przez niego w De consolatione philosophiae personifikacja filozofii jako pięknej pani i podana przez niego definicja filozofii jako umiłowanie mądrości ludzkiej stały się jeszcze trwalszą spuścizną i dzieło to doczekało się wielu komentarzy w średniowieczu ${ }^{18}$. Według Boecjusza filozofia jako mądrość zdobyta na podstawie doświadczenia i w wyniku osobistej refleksji ma upo-

${ }^{14}$ C. Morton, Marius of Avenches, the Excerpta Valesiana, and the Death of Boethius, „Traditio“, 38 (1982), s. 107-136.

${ }^{15}$ H. M. K l inke n berg, Der Verfall des Quadriviums im frühen Mittelalter, [w:] J. K o c h (Hrsg.), Artes liberales. Von der antiken Bildung zur Wissenschaft des Mittelalters, Leiden, Köln 1959, s. 2.

${ }^{16}$ K. G. F e 11 e r e r, Die musica in den artes liberales, [w:] Artes liberales..., J. Koch (ed.), s. 33-49.

${ }^{17} \mathrm{~S}$. B r a n d t, Entstehungszeit und zeitliche Folge der Werke von Boethius, „Philologus", 62 (1903), s. 141-154, 234-275; A. P. M c K in l a y, Stylistic Tests and the Chronology of the Work of Boethius, "Harvard Studies in Classical Philology", 18 (1907), s. 123 -156; L. M. D e Rijk, On the Chronology of Boethius' Works on Logic, „Vivarium“, II (1964), s. 1-49, 125-162.

${ }^{18} \mathrm{D}$. S ch a n z e r, The Death of Boethius and the "Consolation of Philosophy", "Hermes", 112 (1984), s. 352-366. 
dabniać do Boga i prowadzić filozofa do zbawienia. Różniła się od wprowadzonej przez Augustyna filozofii Chrystusa (philosophia Christi). Z biegiem czasu stała się cząstką wczesnośredniowiecznej samodzielnej myśli filozoficznej. Triumfy popularności święciła ona w XII wieku, który $\mathrm{z}$ tego powodu bywa niekiedy nazywany stuleciem boecjańskim (aetas Boethiana). Boecjusza cytował Alkuin, Piotr Abelard i Piotr z Lombardii. Oddziałał na katedralną szkołę w Chartres. Komentował niektóre jego dzieła Tomasz z Akwinu. Dokonane przez Boecjusza przekłady jak i De consolatione philosophiae legły u podwalin myśli średniowiecznej ${ }^{19}$. Napisane przez niego dzieła $\mathrm{z}$ zakresu teologii stały się nawet pierwowzorem metody scholastycznej jako zasady łaczenia wiedzy rozumu i prawd wiary bez uciekania się do tekstów Pisma św. jako autorytetu ${ }^{20}$. Do rozwiązywania zagadnień teologicznych wprowadził logiczną argumentację. Przez chęć racjonalnego rozumienia wiary Boecjusz zasłużył na miano pierwszego scholastyka. W zasadzie przyjął arystotelesowski dychotomiczny podział filozofii teoretycznej ${ }^{21}$. Tylko do logiki ograniczał się w ujęciu Boecjusza wpływ Arystotelesa aż do XII wieku na łacińskim Zachodzie. O ile u Porfiriusza przy rozwiązaniu problemu uniwersaliów pojawiło stanowisko zarówno platońskie jak i arystotelesowskie, o tyle Boecjusz opowiedział się raczej za tym ostatnim ${ }^{22}$. Na wczesne średniowiecze Boecjusz oddziałał przez nową filozoficzną problematykę, terminologię i wiele trafnych definicji $i^{23}$.

W okresie przejścia od późnego antyku do wczesnego średniowiecza doszło do rozdzielenia literatury i języka. Dla ludów germańskich i ludzi mó-

${ }^{19}$ E. K. R a n d, Founders of the Middle Ages, Cambrige, Massachuusetts 1928, s. 135.

${ }^{20}$ „Fidem, si poteris, rationemque coniunge” - „Połącz, jeśli możesz, wiarę i rozum”. Cyt. J. P i e p e r, Scholastyka. Postacie i zagadnienia filozofii średniowiecznej, przekł. T. Brzostowski, Warszawa 1963, s. 32.

${ }^{21}$ Boecjusz dzielił filozofię na teoretyczną i praktyczną. W pierwszej z nich traktującej o naturze rzeczy wyróżnil z kolei trzy dziedziny: intellectibilia (oddzielone od materii istoty duchowe - stanowią przedmiot teologii); intelligibilia (dusze ludzkie) i naturalia (świat cielesny zajmuje się nimi quadrivium). „Nam cum tres sint speculatiue partes: Naturalis in motu inabstracta anypexairetos i.e. inseparabilis. Considerat enim corporum formas cum materia que a corporibus separari non possunt. Que corpora in motu sunt: ut cum terra deorsum, ignis sursum fertur. Habetque motum forma materie coniuncta. Mathematica sine motu inabstracta. Hec enim formas corporum speculatur sine materia ac per hoc sine motu. Que forme cum in materia sint, $\mathrm{ab}$ his separari non possunt. Theologica sine motu abstracta atque separabilis. Nam dei substantia et materia et motu caret". - An i ci Manli i Seuerini Boeti i, De sancta Trinitate, [w:] The Commentaries on Boethius, by Gilbert of Poitiers, ed. N. M. Häring, Toronto 1966, s. 371, w. 1-13. Boecjusz podał także ich odrębną metodę postępowania w każdej z tych dyscyplin: „In naturalibus igitur rationaliter, in mathematicis disciplinaliter, in diuinis intellectualiter uersari oportebit". - Tamże, w. 14-15. Filozofia praktyczna obejmuje także trzy części: o jednosce, o państwie i rođzinie. Ze względu na własny przedmiot logika jest samodzielnym działem filozofii. Z racji, iż jako metoda służy innym działom filozofii, jest ich narzędziem. R. H e in z m a n n, Filozofia średniowieczna, przekł. P. Domański, Kęty 1999, s. 89-90.

${ }^{22}$ Texte zum Universalienstreit. I: Vom Ausgang der Antike bis zur Frühscholastik, lateinische, griechische und arabische Texte des 3.-12. Jahrhunderts übersetzt und herausgegeben von H.-U. W ö h 1 e r , H.-U. Wöhler (ed., tł.), Berlin 1992, s. 21-36.

${ }^{23}$ Anicii Manlii Seuerini Boetii De bonorum ebdomade, [w:] The Commentaries on Boethius, by Gilbert of Poitiers, s. 380-383; t e n ż e, Contra Euticen et Nestorium, tamże, s. 384-400. 
wiących dialektami romańskimi łacina nie była bowiem językiem ojczystym. Pozostała jedynie językiem literatury, Kościoła i w jakimś stopniu życia politycznego. Łaciny uczono się, ażeby zrozumieć łacińskie teksty i aby porozumieć się. Z biegiem czasu doszło do tego jeszcze pragnienie pięknego i eleganckiego wyrażania się w tym języku. Do tego nie wystarczała nauka gramatyki. Trzeba było także nauczać retoryki ${ }^{24}$. Do przekazywania skarbów wiedzy potrzeba było nauczycieli i szkół jako wolnych przestrzeni gwarantujących swobodę nauczania i uczenia się.

Z pochodzenia Syryjczyk a $\mathrm{z}$ urodzenia Rzymianin K a s jo d or (ok. 485 - ok. 580) był prawdopodobnie uczniem Boecjusza. Doszedł do znacznych wpływów na dworze Teodoryka przez zajmowanie się oświatą. Około 529 roku Kasjodor i papież Agapet powzięli zamiar założenia w Rzymie swego rodzaju uniwersytetu według wzorów aleksandryjskich i syryjskiej Nisibis. Niestabilna sytuacja polityczna i niedostateczny rozwój szkolnictwa zachodniego uniemożliwiły wprowadzenie w życie tej pierwszej zachodniej idei uniwersyteckiej ${ }^{25}$. Gdy Kasjodorowi nie powiodła się próba założenia uniwersytetu na zachodzie, to chciał chronić duchową spuściznę antyczną we wspólnocie klasztornej, która była nietykalna ze strony władz świeckich. W związku z tym przeniósł się wraz swoim ogromnym księgozbiorem obejmującym grecko-rzymską poezję, filozofię i historię $e^{26}$ do klasztoru Vivarium, gdzie wprowadził zwyczaj przepisywania klasycznych tekstów antycznych i napisał w sposób przystępny zbiór encyklopedycznych wiadomości przeznaczonych głównie dla mnichów w Institutiones saecularium lectionum i Institutiones divinarum lectionum. Chociaż obie części tego dzieła były kompilacją ocalałego dorobku naukowego, stały się ważnym źródłem encyklopedycznym dla późniejszych wieków. W Institutiones bowiem znalazły się ważne określenia filozofii jako poznania rzeczy boskich i ludzkich, jako nauki o naukach, jako rozważania o śmierci czy wreszcie jako nauki umierania. Dzięki działalności Marcjana Capelli, a zwłaszcza Kasjodora w powstającej pedagogice Zachodu pojawiła się wiedza świecka, która nie była tak ściśle związana z myśłą chrześcijańską jak u Augustyna. Gdyby na progu średniowiecza nie byłby pojawił się Kasjodor, to trudno wyobrazić sobie późniejszą działalność pedagogiczną Alkuina na dworze Karola Wielkiego i Hrabana Maura, który wprowadził do filozofii neoplatonizm, utożsamił ją $\mathrm{z}$ światopoglądem i powiązał $\mathrm{z}$ teologią.

W VI wieku wzrosła również rola zakonów jako instytucji zajmujących się także wykształceniem. Na niwie edukacji zakonnej decydujący krok uczynił przynależący jak Boecjusz do rzymskiego rodu Anicjuszów i współczeny Kasjodorowi św. B e n e d y k z z N u s j i (ok. 480-547) ${ }^{27}$. Jego model

${ }^{24}$ A. W e is c he, Zur Bedeutung der römischen Rhetorik, [w:] Latein und Europa. Traditionem und Renaissancen, Stuttgart 1978, s. 151.

${ }^{25}$ J. P i e p e r, Scholastyka..., S. 37.

${ }^{26} \mathrm{~W}$ średniowieczu zaniedbano naukę historii. H. W o It $\mathrm{e}$, , Geschichtliche Bildung im Rahmen der artes liberales, [w:] Artes liberales..., J. Koch (wyd.), s. 50-83.

${ }^{27}$ P. S c zani e cki, Benedykt z Nursji św., [w:] Encyklopedia katolicka, t. 2, Lublin 1985, kol. 228-229. 
wykształcenia bywa określany jako lektura ksiag Bożych (lectio divina). Edukacja benedyktyńska odegrała dużą rolę w ruchu monastycznym w następnych wiekach. Zarówno Kasjodor jak i Benedykt przez zakładanie skryptoriów i poprzez nakazanie czasochłonnego i żmudnego przepisywania reliktów starożytnej wiedzy przyczynili się bardzo do ocalenia ich od zupełnej zagłady i do wykonania wzniosłej misji kulturalnej ${ }^{28}$.

Gdy w VI wieku Imperium Rzymskie wraz ze swoją kulturą chyliło się ku upadkowi, to urodzony około 540 roku w patrycjuszowskiej familii rzymskiej, późniejszy mnich, od około 585 roku opat klasztoru benedyńskiego w Monte Celio i od 3 września 590 roku papież G r z e g o r z I starał się niektóre relikty zanikającego rzymskiego dorobku kulturalnego wykorzystać dla rodzacego się chrześcijańskiego życia umysłowego i dla utworzenia podwalin średniowiecznego Kościoła. Jego zasługi w tym względzie, twórczość pisarska (np. Moralia in "Job»), poczynania reformatorskie w liturgii kościelnej (,śpiew gregoriański") i organizacja papiestwa sprawiły, że tego papieża nazwano Wielkim.

W VII wieku pod wpływem monastycyzmu utrwaliło się przekonanie, że tylko sama Biblia powinna być jedynym źródłem wiedzy. Trwało ono do renesansu karolińskiego ${ }^{29}$.

We wczesnym średniowieczu w Europie nieliczne szkoły istniały nie tylko przy klasztorach, lecz także przy katedrach. Z tej racji niektórzy przedstawiciele kleru diecezjalnego troszczyli się również o życie umysłowe i wykształcenie w podległych im szkołach. Wspomnieć wypada wielkiego kompilatora VII wieku, I z y d o r a ( $†$ 636), arcybiskupa Sewilli, który około 600 roku napisał słynne Etymologiae. W dwudziestu księgach tej encyklopedii podał on wiele definicji i pojęć z ówczesnych dziedzin wiedzy zebranej z gasnącej klasycznej kultury antycznej i stanowiących przez długi okres czasu wprowadzenie do rozwoju życia umysłowego w zachodniej Europie. W dziele tym znalazły się także sentencje, czyli obowiązujące główne tezy wyjęte z pism ojców Kościoła.

Słowo scola jest greckiego pochodzenia. Gilbert z Poitiers ( $\dagger$ 1154) uważał, że oznacza ono dyscyplinę, której się naucza ${ }^{30}$. Do końca XII słowo scholae odnoszono raczej do wspólnoty, którą tworzył nauczyciel ze swoimi uczniami. Piotr Abelard używał tego słowa też w liczbie mnogiej ${ }^{31}$. U niego

\footnotetext{
s. $26-27$.

${ }^{29} \mathrm{P}$. R i c hé, Manuels et programme de cours dans l'antiquité tarive et le haut moyen âge, [w:] Manuels, programmes de cours et techniques d'enseignement dans les universitiés médievales, Actes de Colloque international de Louvain-la-Neuve, 9-11 septembre 1993, J. Hamesse (wyd.), Louvain-la-Neuve 1994, s. 3.

${ }^{30}$ „Disciplina quae Grece dicitur scola”. Gilbertus de la Porré e, De hebdomadibus, 2, prol., wyd. N. M. Häring, The Commentaries on Boethius by Gilbert of Poitiers, s. 183.

31 „A regimine scolarum cessare compulsus est". P etr us A b a e lardus, Historia calamitatum, wyd. J. Monfrin, Paris 1962, s. 64, 67.
}

${ }^{28}$ M. M. Hild e brandt, The External School in Carolingian Society, Leiden 1992, 
odnosi się ono już do budowli ${ }^{32}$. Szkoła jako instytucja odgrywała już w tym czasie dużą rolę. Wychowywała nie tylko człowieka. Stała się także ostoją kształtowania się doktryn ${ }^{33}$.

Gdy we wczesnym średniowieczu nastąpiła względna stabilizacja, zaczęto w niektórych większych ośrodkach organizować elementarne nauczanie, które pozostało we większości przypadków pod nadzorem mnichów ${ }^{34}$. Było ono czymś elitarnym. Uczestniczyli w nim chłopcy od siedmiu do piętnastu lat. Obejmowało ono głównie naukę języka łacińskiego. Zaczynała się od poznania alfabetu łacińskiego, pamięciowego opanowania głównych modlitw („Ojcze nasz”, „Zdrowaś Mario”, „Wierzę w Boga Ojca”) i niektórych psalnów. Do tego doszła nauka śpiewu, potem także czytania, pisania i liczenia. Gramatyka była najważniejszą umiejętnością. Bez niej niemożliwa była żadna wiedza. Była bramą do nauki mowy i pisania, a zwłaszcza do opanowania języka łacińskiego. Czyniono to na podstawie niewielkiego podręcznika Ars minor Donata, który w formie dialogu traktuje o ośmiu częściach mowy. Pierwszą książką do czytania były Disticha Catonis nie ze wzlędu na styl i formę wiersza, lecz z racji treści moralizującej. Ponieważ zadaniem elementarnego nauczania było na pierwszym miejscu wychowanie a nie przekazanie wiedzy, spełniały one właśnie taką rolę ${ }^{35}$. Dopiero $w$ późniejszych czasach $^{36}$, zwłaszcza w XII wieku do lektury służyły dzieła auctores minores ${ }^{37}$. Na uwage zasługują anonimowe dzieła Facetus i Floretus oraz zbiór przysłów Alana z Lille. Szkoły o takim profilu nauki nazywano małymi (parvae scholae). Nauka w nich trwała zazwyczaj od dwóch do trzech lat. W niektórych miejscowościach w XII wieku ich liczba była duża ${ }^{38}$. W nauczaniu i wychowaniu podstawowym bardziej chrześcijańska nauka pojawiła się dopiero w późnym średniowieczu.

Byłoby błędem następną fazę w średniowiecznym szkolnictwie ściśle oddzielić od wcześniejszej. Przejście od elementarnej szkoły, będącej głównie szkołą śpiewania do następnego, wyższego etapu polegało na zwiększeniu nauki czytania i pisania. Pod względem nauczanej treści jak przedtem tak

32 „Scolas nostras a se removere conatus (...) Priusquam a suis recederem scolis, nostrarum preparationem scolarum prepediret (...) scolarum nostrarum tiricinio“. Tamże, s. 64; cf. s. 65 i 66.

${ }^{33} \mathrm{P}$. R i c h é, Écoles et enseignement dans le haut moyen-âge, Paris 1984.

${ }^{34}$ Chociaż anachoreci wschodni wytwotrzyli wcześniej niź wspólnie żyjący mnisi zachodni elementy średniowiecznej pedagogiki, to jednak ci ostatni poszli własną droga. H. I. M a r r o u, Histoire de l'éducation dans l'antiquité, Paris 1965, s. 470.

${ }^{35} \mathrm{Ph}$. D e $\mathrm{l}$ h a y e, La place de l'éthique parmi les disciplines scientiques au XII' siècle, [w:] Miscellanea moralia in honorem [...] Arthur Janssen, Löwen 1948, s. 29-44.

${ }^{36} \mathrm{G}$. G $1 \mathrm{a}$ u ch e, Schullektüre im Mittelalter. Entstehung und Wandlungen des Lektürekanons bis 1200 nach den Quellen dargestellt, München 1970 (Münchener Beiträge zur Mediävistik und Renaissance-Forschung, V). kol. 1189.

${ }^{37}$ G. Bernt, Auctores, [w:] Lexikon des Mittelalters, 2, München, Zürich 1983,

${ }^{38} \mathrm{R}$. K ö h n, Schulbildung und trivium im lateinischen Hochmittelalter und ihr möglicher praktischer Nutzen, [w:] Schulen und Studium im sozialen Wandel des hohen und späten Mittelalters, hrsg. von J. Fried, Sigmaringen 1986, s. 221-231. 
i w kolejnym etapie nauczania uczono się nadal języka łacińskiego i gramatyki. Zmieniły się wszakże podręczniki. Na miejsce Ars minor Donata wprowadzono jego Ars maior i Institutiones grammaticae Pryscjana, w których to podręcznikach jest mowa o składnii i stylu. $Z$ biegiem czasu poszerzono także kanon lektur odnośnie auctores minores.

Trwało dosyć długo, bo aż dwa wieki, zanim przedmiotem większego zainteresowania stały się znowu artes liberales $^{39}$, czyli umiejętności lub sztuki wyzwolone $^{40}$. Gdy potraktowano je jako siedem filarów mądrości (sacrae di-

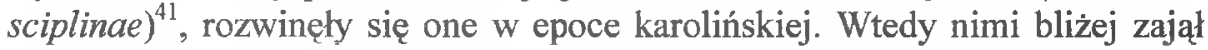
się Alkuin. Jan Eriugena jako przełożony szkoły pałacowej wykładał je na dworze Karola Łysego. Trzy nauki wchodzące w skład tzw. trójdroża (trivium) uznano później za niezbędny element wykształcenia kleru. Przy tym opierano się głównie na napisanym na początku $V$ wieku dziełe późnoantycznego uczonego Marcjana Capelli O malżeństwie Merkurego z filologia i Sumie Pryscjana, starożytnych podręcznikach nauk wyzwolonych ${ }^{42}$. Szkoły zakonne były w zasadzie przeznaczone do kształcenia zakonników. Było ono oparte na regułach zakonnych, które w załążku opracował sam założyciel. Gdy około 1100 wzrosła liczba nowozakładanych klasztorów, powstało również więcej szkół zakonnych. Późniejsze kapituły precyzowały i uzupełniały program nauczania. Podstawą nauczanych w zakonach wiadomości biblijnych była lektura (lectio) i rozmyślanie (meditatio). Przy tym pojawiały się często tendencje do mistyki. Nauczaniu tego czasu obca była dysputa (disputatio) ${ }^{43}$.

Zadaniem szkół katedralnych zaś było przygotowanie kleru do zadań duszpaterskich w diecezji. Ich głównym celem była nauka czytania, śpiewu i odpowiedniego wyjaśniania Biblii (lectura divina), dająca nie tylko niezbędną wiedze teologiczną lecz także wiadomości kształtujące światopogląd chrześcijański $^{44}$. Na czele szkół katedralnych stał z reguły członek kapituły. Początkowo był to archidiakon albo kanclerz. Potem $\mathrm{z}$ członków kapituły wybierano człowieka wykształconego, którego nazywano w różny sposób: magister scholarum, caput scholae, a później scholasticus. Na gruncie szkół katedralnych tylko w bardzo nielicznych przypadkach wyrosły później uniwersytety.

39 „The Latin phrase artes liberales reflects the dependence of Roman education on Greek culture: it is the equivalent for enkuklios paideia, the Greek term most commonly used to characterize the curriculum of secondary education. The Roman tradition in turn became the model for Christian culture and education, although the attitude of Christians toward the pagan tradition was extremely ambiguous, as the following essay makes clear". K. F. Mor r is o n, 2 Incentives for Studying the Liberal Arts, [w:] The Seven Liberal Arts in the Middle Ages, ed. by D. L. Wagner, Bloomington 1983, s. 32.

${ }^{40} \mathrm{H}$. G. W a $1 \mathrm{th}$ e $\mathrm{r}$, Die Anfänge des Rechtsstudiums und die kommunale Welt Italiens im Hochmittelalter, [w:] Schulen und Studium..., s. 121.

${ }^{41} \mathrm{~A} . \mathrm{K}$ i j e w s k a, Księga pisma i księga natury. Heksaemeron Eriugeny $i$ Teodoryka $z$ Chartres, Lublin 1999, s. 56.

${ }^{42} \mathrm{~S} . \mathrm{D}$ 'I $\mathrm{r} \mathrm{s}$ a y, Histoire des universités francaises et étrangères des origines a nos jours, I: Moyen Age et Renaissance, Paris 1933, s. 44.

${ }^{43}$ P. J o h a n e k, Klosterstudien im 12. Jahrhundert, [w:] Schulen und Studium..., s. 43.

${ }^{44}$ A. W e n d e h ors t, Wer konnte im Mittelalter lesen und schreiben?, [w:] Schulen und Studium..., s. 9. 
Obok wymienionych szkół zaczęły od przełomu VII i VIII wieku we Włoszech i Francji także powstawać szkoły prawa i medycyny. Nauczyciele pierwszych z nich starali się od zupełnej zagłady ocalić prawo rzymskie, objaśniając zachowane pisma prawnicze, a zwłaszcza powstały w VI wieku system prawny wschodniego państwa rzymskiego, który zawierał Kodeks Justyniana (Codex Justinianus). Absolwenci tych szkół byli zatrudniani w administracji miejskiej i na dworach. Ówczesny teolog miał być też zorientowany w prawie. W położonym w południowej Francji Montpellier od VIII wieku istniała szkoła medycyny. Jej znaczenie wzrosło w XII wieku ${ }^{45}$. Uczono przede wszystkim arabskiej sztuki lekarskiej. Około połowy IX wieku Arabowie bowiem posiadali już starożytne pisma naukowe. Znali całego Arystotelesa i czytali Galena, a także Corpus Hippocraticum. W tym czasie lekarz posiadał także wykształcenie filozoficzne, co więcej, dobry lekarz musiał być filozo$\mathrm{fem}^{46}$. Wymienione szkoły już przed XII wiekiem zwano studiami partykularnymi (studium particulare). W ten sposób w IX i X wieku nazywano niekiedy paryskie szkoły klasztorne i szkołę katedralną. Ich wspólną cechą było to, że nie starały się one objąć całości ówczesnej wiedzy. Wobec tego szkół czy studiów partykularnych nie można nazwać uniwersytetami. Ich powstanie było o wiele bardziej złożone: wiązało się nie tyle $\mathrm{z}$ tradycją ile ze zmianami społeczno-wychowawczymi w okresie pomiędzy XI i XIII wiekiem ${ }^{47}$.

Wiek IX odegrał poważną rolę w życiu umysłowym na kontynencie europejskim Zachodu. Poczynania kulturalne tego stulecia otrzymały nazwę odrodzenia karolińskiego, gdyż wspierał je na swoich terytoriach Karol Wielki († 814), który przy tworzeniu monarchii czerpał ze wzorów starożytnych. Najbardziej rozwinęły się one na terenie Francji. Były oparte na wywodzącej się ze starożytnego dorobku łacińskiego kulturze anglosaskiej, do której powstania w Wielkiej Brytanii przyczyniły się m. in. prace misyjne Augustyna z Canterbury ( $\uparrow 604$ ), pisma Bedy Czcigodnego (673-735) i działalność dydaktyczna w katedralnej szkole w Yorku A l k u i n a (ok. 730-804). Gdy Karol Wielki zaprosił go do Francji, to chciał w tym kraju stworzyć Ateny chrześcijańskie, w którychby nie tylko przekazywano wiedzę boską (scientia divina), lecz także uczono nauk humanistycznych wraz z literaturą (scien-

${ }^{45} \mathrm{~S}$. Gu e né e, Bibliographie de l'histoire des universités françaises des origines á la Révolution, t. 2, Paris 1978, s. 198.

${ }^{46} \mathrm{H}$. S c h i p p e r ge s, Die Rezeption arabisch-griechischer Medizin und ihr Einfluss auf die abendländische Heilkunde, [w:] Die Renaissance der Wissenschaften im 12. Jahrhundert, wyd. P. Weimar, Zürich 1981, s. 173.

${ }^{47}$ Trudno jednak zgodzić się w całości z takim wyjaśnieniem powstania uniwersytetów: "L'università è figlia della rivoluzione demografica, stradale, urbana, commerciale dei secoli XI-XIII: essa è strettamente conessa con la città, con la strada, con la fluidità del clero minore e il suo proporsi quale cerniera sociale e culturale fra sacerdozio e laicato, con la commercializzazione del sapere e la nascita delle professioni liberali, con il dibattito teologico e la sua connessione profonda con l'emergere dell'inquietudine ereticale, il frasi forza sociale di tale inqietudine - una «sfida» - e la risposta a tale "sfida» costituita dalla necessità di rispondere, con la dialettica, con la propaganda e con la repressione, a tale inquietudine". F. C a rdin i, M. T. F u magalli B e o n o-B r o c ch i e ri, Antiche università d'Europa. Storia e personaggi degli Atenei nel Medio Evo, Milano 1991, s. 29. 
tiae disciplinarum litterarumque). W ten sposób oprócz tzw. szkół zamkniętych dla mnichów powstały jeszcze tzw. szkoły otwarte dla ludzi świeckich. Ich liczba była wprawdzie jeszcze niewielka, ale odtąd nauczanie nauk świeckich powoli nabiera samodzielności. Według Alkuina artes liberales a spośród nich zwłaszcza dialektyka miały nie tylko odgrywać większą rolę w wykształceniu, lecz także służyć przy objaśnianiu tekstów Pisma św. Uczeń i następca Alkuina na stanowisku opata Saint Martin w Tours, F r e d e g i s u s († 834) ożywił jeszcze bardziej ich studium.

Po 827 roku na zachodnią doktrynę zaczęła oddziaływać także grecka myśl teologiczna w ujęciu platońskim. W tym bowiem roku cesarz Michał Balbus przesłał Ludwikowi Pobożnemu tzw. Corpus Aeoropageticum lub Corpus Dionysiacum. Jego autorem miał być rzekomo uczeń św. Pawła, o którym mowa w Dziejach apostolskich $(17,34)$. Dzięki temu zyskało ono niebywałą popularność, gdy jego dosłownego przekładu w latach 860-862 dokonał Jan Eriugena ${ }^{48}$. Corpus Dionysiacum zdradza wpływy późnego neoplatonizmu i platonizmu chrześcijańskiego. Nawiązywało też do Orygenesa, Grzegorza z Nysy (334-394), zwłaszcza Proklosa (410-485), którego niektóre tezy neoplatońskie zostały zinterpretowane po chrześcijańsku. Składało się z czterech traktatów: De divinis nominibus, De theologia mystica, De hierarchia caelestia i De hierarchia ecclesiastica. Ze względu na fałszerstwo autora w hierarchii średniowiecznych autorytetów zajęło zaszczytne miejsce po Piśmie św. Urosło niemal do rangi apostolskiego autorytetu. Tymczasem rzeczywistym autorem Corpus Aeoropageticum był mnich działający na przełomie V i VI wieku w Syrii. Dzięki niemu w zachodnim spirytualizmie przyjęła się praplatońska koncepcja o trzech stopniach wznoszenia się do doskonałości: oczyszczenie, oświecenie i zjednoczenie ${ }^{49}$. Dionizyska myśl o hierarchii znalazła swoje odbicie w zachodniej racjonalnej wizji społeczeństwa. Widać to u Eriugeny w Periphyseon (De divisione naturae), Homiliach do prologu «Ewangelii» Jana i komentarzu do "Ewangelii» Jana ${ }^{50}$. Poprzez pisma Dionizego, zwłaszcza $O$ imionach Bożych na łacińskim Zachodzie pojawiła się negatywna filozofia i teologia, co stało w kontraście do zachodniego racjonalizmu (ratio) dążącego do wyjaśnień pozytywnych. Według Dionizego człowiek nie może Bogu nadać żadnego imienia, gdyż Bóg jako jedność znajduje się poza i ponad bytem. W tym przypaku człowiek jest skazany całkowicie na to, co objawiło Pismo św. Wpływów Dionizego pseudo-Areopagity na myśl średniowieczną można doszukiwać się wszędzie tam, gdzie rzeczywistość jawi się rozumowi ludzkiemu jako niezgłębiona i tajemna i gdzie występuje neoplatonizm zależny od Plotyna. Niektóre pisma Dionizego komentowali nawet Albert Wielki

${ }^{48}$ Wcześniej, w latach 827-835 trudno zrozumiałego przekładu Corpus Aeoropageticum dokonał opat Hilduin. Trzecie, poprawniejsze thumaczenie ukazało się w połowie XII w. Dokonał tego Jan Saracen. Od tego staranniejszy był trzynastowieczny przekład Roberta Grossetesta.

${ }^{49}$ Do tej myśli nawiązywali jeszcze w XVI w. tak wielcy mistycy hiszpańscy jak Teresa z Awili i Jan od Krzyża. J. P i e p e r, Scholastyka..., s. 47.

${ }^{50}$ G. S c h rimp f, Das Werk des Johannes Scotus Eriugena im Rahmen des Wissenschaftsverständnisses seiner Zeit. Eine Hinführung zu Periphyseon, Münster 1982, s. 1 n. 
i Tomasz z Akwinu. Na Zachodzie Dionizy wytyczył drogę do rozwoju mistyki. Jej wpływy pojawily się u Jana Eckharta, Jana Taulera, Jana Ruysbroeka, Dionizego Kartuza. Najwyraźniej zaś wystapiły w „wiedzącej niewiedzy” u Mikołaja z Kuzy w połowie XV wieku. Charakteryzująca się większą samodzielnością filozofia Eriugeny miała służyć do roztrzygnięcia spornych zadagnień w teologii.

Jeszcze w IX stuleciu do Francji przybyło wielu irlandzkich gramatyków i dialektyków, którzy stali się nauczycielami ${ }^{51}$. Wśród tych przybyszów znalazł się także J a n Eri u g e n a ze S z k o c j i (ok. 810-ok. 877), mówiąc ściślej w Irlandii (Scotia maior), przedstawiciel chrześcijańskiej wersji neoplatonizmu ${ }^{52}$ łączący odmianę augustyńską i dionizjańską ${ }^{53}$. U niego po raz pierwszy spotkały się te dwa typy neoplatonizmu. Przez nawiązanie do tradycji greckiej na podstawie tekstów Grzegorza z Nysy, Maksyma Wyznawcę a zwłaszcza Dionizego Pseudo-Aeropagity stworzył na łacińskim Zachodzie inną filozofię o orientacji neoplatońskiej, która nie była tak ściśle związana z myślą chrześcijańska jak u Augustyna. Dzięki Eriugenie w nauczaniu zaczęła się utrwalać samoistna wartość artes liberales. W tej epoce darzono je także mianem filozofii. Wśród nich podstawowe znaczenie posiadała dialektyka określana jako mater artium. U Eriugeny dialektyka nie była już ars lub disciplina, lecz urosła do rangi scientia, czyli wiedzy, a nawet nauki. W centrum dialektyki znalazła się bowiem nauka o dziesięciu kategoriach opisujących rzeczywistość. Dialektyka stała się odtąd narzędziem myślenia naukowego. Eriugena poświęcił także wiele uwagi quadrivium. Naśladując go, uczyniono to też w szkołach w Laon i Auxerre. Przez stosowanie reguł logiki ${ }^{54}$ wprowadził nową metodę naukową (modus disciplinae). Zasadzała się ona na dwóch zasadach na rozpatrywaniu rzeczywistości od jedności - absolutu do bytów indywidualnych (divisio) i od wielości do jedności (analysis lub resolutio). Rozpatrywana przez prawdziwy przyrodzony rozum (recta ratio naturalis) przenikająca się nawzajem problematyka filozoficzna i teologiczna otrzymała znamiona spekulacji teologicznej ${ }^{55}$. Eriugena zastosował w swoim głównym dziele noszącym tytuł grecki Periphyseon i łaciński De divisione naturae ${ }^{56}$,

${ }^{51} \mathrm{~J} . \mathrm{S}$ t r z e l c z y k, Iroszkoci w kulturze średniowiecznej Europy, Warszawa 1987.

52 J. K o c h, Augustinischer und Dionysischer Neuplatonizmus und das Mittelalter, [w:] Platonismus in der Philosophie des Mittelalters, wyd W. Beierwaltes, Darmstadt 1969, s. 317-342 .

53 A. K i jewska, Neoplatonizm Jana Szkota Eriugeny. Podmiotowe warunki doświadczenia mistycznego $w$ tradycji neoplato $\mu$ skiej, Lublin 1994, s. 18.

${ }^{54}$ Jan Eriugena znał logikę arystotelesowską głównie z pseudo-Augustyńskiego traktatu Categoriae decem. - Tamże, s. 86.

${ }^{55}$ M. C a p p y n s, Jean Scot Érigène. Sa vie, son oeuvre, sa pensée, Louvain-Paris 1933 , s. 302 in.

${ }^{56}$ „Videtur mihi divisio naturae per quattuor differentias quattuor species recipere, quarum prima est in eam, quae creat et non creatur, secunda in eam, quae et creatur et creat, tertia in eam, quae creatur et non creat, quarta, quae nec creat, nec creatur". I o a n n e s S c o tu S E r i u g e n a , Periphyseon, liber primus, wyd. I. P. Sheldon-Williams, I, Dublin 1968, s. 1. 
i przy komentowaniu Księgi Rodzaju ${ }^{57}$. Pierwsze z wymienionych dzieł jest podręcznikiem dotyczącym nie tylko sztuk wyzwolonych, lecz także mądrości chrześcijańskiej zawierającej prawdę o Bogu, świecie i człowieku. Prawdziwej mądrości dostarcza dopiero przyjęte przez wiarę Objawienie, które stoi na początku wszelkiej spekulacji. Najistotniejszą cechą Boga, który jest istotą wszystkiego (essentia omnium), jest nieskończoność ${ }^{58}$. Tak więc Eriugena założenia chrześcijańskie rozpatrywał na gruncie neoplatońskiego esencjalizmu. Po śmierci Karola Łysego († 877) w wyniku najazdów Normanów doszło do zahamowania rozwoju utworzonej przez niego szkoły filozofii. Dzięki znajomości dorobku Dionizego Pseudo-Areopagity Eriugena stworzył szereg nowych koncepcji i wypowiedział śmiałe myśli, które fascynowały późniejszych myślicieli zachodnich. E r i u g e $\mathrm{n}$ i z $\mathrm{m}$ jest $\mathrm{w}$ zasadzie syntezą neoplatonizmu i chrześcijaństwa, filozofii i religii, jednością rozumu i wiary. Filozofia Eriugeny stanowi pośrednie ogniwo pomiędzy Boecjuszem i Anzelmem z Canterbury ${ }^{59}$. Jednak podejrzenie o panteizm (Deus est omnia) sprawiło, że oddziałał on tylko pośrednio i w późniejszym czasie. W XII wieku byli to Teodoryk z Chartres i Honoriusz z Augsburga (Augustodonensis). Wielkie uznanie znalazł on dopiero u Mikołaja z Kuzy. Pośrednio wpływy jego myśli ujawniły się nawet u niektórych przedstawicieli niemieckiego idealizmu.

$\mathrm{Z}$ tzw. świeckich nauk w X wieku w klasztorach pielęgnowano w zasadzie nauke gramatyki i logiki. Niekiedy doszła jeszcze nauka muzyki ${ }^{60}$. Zarówno w szkołach klasztornych i katedralnych jak i na uniwersytetach podstawowym podręcznikiem do nauki muzyki był traktat Boecjusza De institutione musica $^{61}$. W pierwszej połowie kolejnego stulecia wybuchły spory dotyczące możliwości zastosowania dialektyki przy rozwiązywaniu problematyki teologicznej. W X i XI wieku wzrosła liczba szkół katedralnych i klasztormych w Niemczech i Francji ${ }^{62}$.

W drugiej połowie XI wieku zaczęli już pojawiać się uczeni, którzy zrobili międzynarodową karierę naukową. $Z$ nich wypada wymienić benedyktyna $\mathrm{L}$ a f r a n k a $\mathrm{z}$ P a w i i ${ }^{63}$, sławnego nauczyciela prawa $\mathrm{i}$ nauk wyzwolonych. Uczył on w Bec w Normandii. Później zasiadł on na stolicy arcybiskupiej w Canterbury. Jego wybitnym uczniem był urodzony 1033 roku w Aosta syn lombardzkiego szlachcica, A n z e l m († 1109). Od późniejszych

${ }^{57}$ I o a n nes S cotus Eriugena, Commentaire sur l'Évangile de Jean, éd. É. $\mathrm{J}$ e a u n e a u, Paris 1972; tenże, Homilia do prologu "Ewangelii» Jana (fragmenty), przekł. A. K i j e w sk a, ,W Drodze" 9 (1990), s. 78-80.

${ }^{58}$ A. K i j e w s k a, Neoplatonizm Jana Szkota Eriugeny..., s. 114.

${ }^{59} \mathrm{~A} . \mathrm{K}$ i j e w s k a, Ksiega pisma i ksiega natury..., s. 80.

${ }^{60} \mathrm{C} . \mathrm{K}$ a d e n, Tonsystem und Mehrstimmigkeitslehre der 'Musica enchiririadis', [w:] M. Kintzinger, S. Lorenz, M. Walter (wyd.), Schule und Schüler im Mittelalter, s. 75-87; C. B e rg e r, Cithara, crbrum und caprea. Wege zum Hexachord, s. 89-109.

${ }^{61} \mathrm{M}$. W a $1 \mathrm{t}$ e r, Sunt preterea multa quae conferri magis quam scribi oportet. Zur Materialität der Kommunikation im mittelalterlichen Gesangsunterricht, [w:] Schule und Schüler im Mittelalter, M. Kintzinger, S. Lorenz, M. Walter (wydawcy), s. 114.

${ }^{62} \mathrm{~J}$. E h 1 e r s, Dom- und Klosterschulen in Deutschland und Frankreich, s. 20-52.

${ }^{63} \mathrm{H}$. K o h l e n b e r ge r, Zur Geschichte des Denkens im 11. Jahrhundert, [w:] Philosophy and Science in the Middle Ages, t. 1, Dordrecht, Boston, London 1990, s. 76. 
miejscowości swojego pobytu zwany jest także Anzelmem z Bec, gdzie został przeorem mając lat trzydzieści, i Canterbury. Zyskał wielki autorytet. Zwano go nawet drugim Augustynem (alter Augustinus). Stał się uczonym trzech narodów. Przyczynił się do mądrego rozwiązania dwóch źródeł wiedzy, tj. rozumu i wiary. Zdaniem św. Anzelma zrozumienie prawd wiary zakłada uprzednią wiare („Neque enim quaero intelligere ut credam, sed credo ut intelligam”64). Wielkie uznanie zyskała też jego wypowiedź: „Fides quarens intellectum". W ten sposób sformułował on w sposób dobitniej boecjańską zasadę połączenia wiary i rozumu i przeprowadził ją konsekwentnie w swoim racjonalizmie. Chociaż Anzelm stanął po stronie Platona i Augustyna, jest on jednym $\mathrm{z}$ tych nielicznych myślicieli filozoficzno-teologicznych, którzy nie ulegli neoplatońskim wpływom negatywnej teologii Dionizego pseudo-Areopagity, chociaż znał on jego pisma.

Czas rozkwitu szkół benedyktyńskich trwał w zasadzie do połowy XII wieku. W tym czasie podupadły one z powodu rozluźnienia dyscypliny zakonnej. Mimo że w następnym stuleciu w niektórych klasztorach podniosła się karność zakonna, nie wybiły się one na niwie naukowej. Nad nauczaniem w zakonie czuwał nauczyciel szkoły (magister scholae, magister puerorum). Jego program nauczania miał głównie na uwadze udział w nabożeństwach kościelnych i zachowanie się w obrębie klasztoru. $Z$ tego względu ze szkół benedyktyńskich nie wziął swojego początku żaden uniwersytet w średniowieczu. Niemal to samo co o benedyktynach można powiedzieć o szkołach kanoników regularnych. Prowadzone w nich nauczanie było podporządkowane służbie w chórze i pracy duszpasterskiej. Cystersi pielęgnowali mało nauki wyzwolone. Tworzyli oni szkoły tylko przy niektórych klasztorach ${ }^{65}$. Troszczyli się głównie o uprawę ziemi. W stosunku do wyżej wymienionych szkół zakonnych dalej w szkolnictwie poszli dominikanie. W swoich statutach z 1228 roku uregulowali oni jako pierwsi sprawę nauki. Stanowiła ona nawet jeden $z$ celów zakonu. Niemniej nauka umiejętności wyzwolonych była tylko wyjątkiem. Studia zakonne były głównie skierowane na egzegezę Pisma św. W franciszkańskim programie nauczania z 1260 roku nie przewidywano wcale nauki artes liberales. Podobnie było przy końcu XIII wieku też w szkołach eremitów regularnych św. Augustyna i karmelitów. Przy takim stosunku wymienionych zakonów do nauki umiejętności wyzwolonych uniwersytety nie mogły z nich wziąć swojego początku.

Po karolińskim odrodzeniu szkolnego nauczania nastapił $r$ e $n$ e s a n s $\mathrm{X}$ I I $\mathrm{w}$ i e $\mathrm{k} \mathrm{u}$, przez który należy rozumieć przede wszystkim ponowny rozkwit nauk $^{66}$, zwłaszcza zaś łaciny klasycznej, łacińskiej poezji, prawa rzymskiego $i$ odkrycie greckiej filozofii z dodatkami arabskimi oraz początki europejskich uniwersytetów. Pod tym względem był on inny od włoskiego renesansu literatury i poezji w XV wieku, który był o wiele większym ruchem

\footnotetext{
${ }^{64}$ Anzelm z Canterbury, Proslogion, I, s. 227.

${ }^{65} \mathrm{R}$. S chn e ider, Studium und Zisterzienserorden, [w:] Schulen und Studium...,

${ }^{66} \mathrm{Ch} . \mathrm{H} . \mathrm{H}$ a s k in s, The Renaissance of the Twelft Century, Cambridge, Mass. 1927.
} s. $321-350$. 
umysłowym i ogarnął niemal całą Europę. Niemniej XII wiek stał się pod niektórymi względami także czasem przełomu. W nim bowiem dotychczasowy światopogląd, przejęte porządki kościelne i panujące urządzenia polityczne stanęły pod znakiem zapytania. Zaczęło natomiast rozkwitać rzemiosło. Częstsze stały się też podróże lądowe i morskie. Krzyżowcy, pielgrzymi, rycerze, handlarze, klerycy i wędrujący scholarzy poznali obce kraje, inne narody i nowe kultury nie tylko na łacińskim Zachodzie, lecz także na greckim Wschodzie i w świecie arabskim. Od księży diecezjalnych zaczęto żądać czystości, a od zakonników wymagać ubóstwa i ascezy. Nowości, z którymi spotkał się człowiek, postawiły go przed nowym wezwaniem. Europejczyk XII wieku je podjął. Powstał głód wiedzy. Uczeni tego stulecia byli świadomi swoich wielkich zadań. Starali się przejąć wiedzę starożytnią i poznać kulturę arabską ${ }^{67}$. Najważniejsze dzieła starożytnych filozofów i lekarzy oraz kodeks prawa cesarza Justyniana jednak pozostały nadal nieznane. Wiedza tego wieku miała $\mathrm{w}$ istocie charakter naukowy i dotyczyła interpretacji tekstów. Powstał też problem wynagradzania ludzi zajmujących się nauką ${ }^{68}$.

Duchowieństwo diecezjalne także zatroszczyło się o szkolnictwo. Obradujący pod przewodnictwem papieża Aleksandra III w 1179 roku trzeci sobor laterański wydał dekrekty, według których każda katedra powinna posiadać szkołę dla kształcenia kleru diecezjalnego. W niej powinien być przynajmniej mistrz, który uczyłby gramatyki ${ }^{69}$ i Pisma św. W tym czasie nauczyciel powinien posiadać odpowiednie beneficjum, które zapewniłoby mu godziwe utrzymanie. Do sprawy wykształcenia kleru diecezjalnego powrócił papież Innocenty III na czwartym soborze laterańskim w 1215 roku. Wtedy nakazano, że takie szkoły do nauczania gramatyki i elementów wiedzy biblijnej należy zakładać także przy kolegiatach. Ich mistrz powinien zaś otrzymać od biskupa odpowienie beneficjum kościelne. Nauczycielem (lector lub magister) szkoły katedralnej lub kolegiackiej początkowo był kanonik. Czwarty sobor laterański zniósł ten wymóg. Chociaż prawo kanoniczne nakazywało duchownym przebywanie przy swoich beneficjach kościelnych, to papież Honoriusz III w wydanej 16 listopada 1219 roku konstytucji apostolskiej zezwolił na pięcioletnią niebecność $w$ rezydowaniu przy posiadanym beneficjum ${ }^{70}$.

Od V do początku XIII wieku w nauczaniu nie pojawiły się takie dyscypliny filozoficzne jak metafizyka, filozofia przyrody, psychologia spekulatywna i filozofia moralna. W tym czasie utrzywała się podana przez Kasjodora cyceroniańska definicja retoryki jako nauki dobrego mówienia w sprawach spoełecznych (bene dicendi scientia in civilibus quaestionibus). W XII wieku

${ }^{67}$ J. A. W e i s h e i p I, Classification of the Sciences in Medieval Thought, „Medieval Studies", 27 (1965), s. 5490.

${ }^{68}$ G. P o s t, K. G i o c a r in is, R. Ka y, The Medieval Heritage of a Humanistic Ideal, «Scientia donum Dei est, ergo vendi non potest», „Traditio”, 11 (1955), s. 195-234.

${ }^{69}$ Przy okazji nauczania gramatyki zaczęto w XII w. podawać także elementy etyki. P. D e Ih a y e, Grammatica et ethica au XIIe siècle, [w:] Artes liberales..., J. Koch (wyd.), s. 91-93.

${ }^{70}$ Chartularium Universitatis Parisiensis, wyd. H. Denifle, E. Chatelain, t. 1, Paris 1889 , s. $90-93, \mathrm{nr} 32$. 
na znaczeniu zyskało jeszcze inne ujęcie retoryki jako teorii dyskutowania $\mathrm{i}$ argumentowania (ars disputandi, dialectica). Większego znaczenia nabrała właśnie dialektyka ${ }^{71}$. Te tendencje wzmogły się po poznaniu arystotelesowskiego organonu. Już w 1030 roku w obiegu były Kategorie Arystotelesa. Dialektykę poszerzono najpierw o tzw. logikę starą (ars lub logica vetus), w której podstawowy skład schodziły Kategorie (K $\alpha \tau \eta \gamma o p 1 \alpha 1$, Categoriae, Praedicamen-

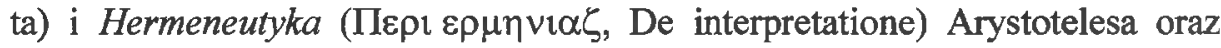
Isagoga Porfiriusza, a od około 1130 roku doszła jeszcze tzw. logika nowa (ars lub logica nova), która obejmowała Analityki pierwsze (Av $\alpha \lambda \nu \tau 1 \kappa \alpha \pi \rho \circ \varepsilon \rho \rho$, Analytica priora), Analityki wtóre (Av $\alpha \lambda \cup \tau 1 \kappa \alpha \pi \rho \circ \tau \varepsilon \rho \alpha$, Analytica posterio-

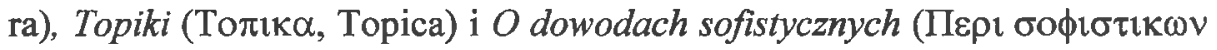
$\varepsilon \lambda \varepsilon \gamma \chi \omega \nu$, De sophisticis elenchis). W XII wieku w programie szkolnego nauczania nauki wyzwolone stanowią nadal integralną część szeroko pojętej filozofii. Należy dodać, że Retoryka Arystotelesa nie wywarła prawie żadnego wpływu na średniowieczne umiejętności wyzwolone, gdyż uważano ją za traktat polityczno-etyczny ${ }^{72}$. To dzieło zaczęto komentować dopiero w drugiej połowie XV wieku' ${ }^{73}$.

W XII stuleciu zmienił się stosunek teologii i filozofii do septem artes liberales. Pojawiło się już wyraźne zainteresowanie zagadnieniami filozoficznymi $^{74}$ i teologicznymi ${ }^{75}$. Przy ich rozwiązywaniu zaczęto stosować metodę logicznej argumentacji. Doprowadziło to do wytworzenia nowej jednostki literackiej zwanej kwestią (quaestio). W niej w formie pytania lub watpliwości (dubitatio) postawiono problem, który starano się rozwiązać, argumentując za (pro) i przeciw (contra), by w ten sposób dojść do odpowiedzi (sformułowanej $\mathrm{w}$ słowach respondeo dicendum $\mathrm{w}$ corpus articuli). Ostateczne rozwiazanie postawionego zagadnienia podawal magister lub doktor (determinatio). W ten sposób obok autotytetów przeszłości (auctoritas), za jakie uchodziło Pismo św. tak Starego jak i Nowego Testamentu i teksty ojców Kościoła z okresu patrystyki, w średniowiecznym myśleniu zajęła argumentacja rozumowa ( $r a-$ tio). Dała ona poczatek tzw. metodzie scholastycznej. Stosując ją dialektycy coraz częściej zajmowali się sprawami dotyczącymi fides i ratio i torowali drogę do utworzenia racjonalnego podejścia $w$ teologii jako nauki $z$ dotychczasowej egzegezy biblijnej opatej na neoplatonizmie i augustynizmie. Wprowadzanie argumentacji logicznej do wyjaśniania Pisma św., które we wczesnym średniowieczu było najważniejszym przedmiotem studiów i głównym celem wszelkiej uczoności, nie odbywało się bez oporów ze strony tzw. anty-

${ }^{71} \mathrm{~F}$. V an $\mathrm{S}$ t e e $\mathrm{n}$ ber $\mathrm{g}$ h e $\mathrm{n}$, L'organisation des études au moyen âge et ses répercussions sur le mouvement philosophique, "Revue philosophique de Louvain”, 52 (1954), s. 572-592.

${ }^{72}$ F.-H. R o b in g, Ars, kol. 1023.

${ }^{73}$ G. K. M a in berge r, Aristotelismus, [w:] Historisches Wörterbuch der Rhetorik. t. 1: $A-B i b$, kol. 99-1009.

${ }^{74} \mathrm{O}$. P edersen, Du quadrivium à la physique. Quelques aperçus de l'evolution scientifique au moyen âge, [w:] Artes liberales..., J. Koch (wyd.), s. 107-123.

${ }^{75} \mathrm{~F}$. V an $\mathrm{St}$ e e $\mathrm{n}$ b e r $\mathrm{g}$ h e $\mathrm{n}$, La conception de la philosophie au moyen âge, [w:] Actas del V congreso internacional de filosofia medieval, I, Madrid 1979, s. 42. 
dialektyków. Pojawili się oni zwłaszcza w kręgach monastycznych: Piotr Damiani $(\dagger$ 1072), Otloh ze Św. Emmerama († 1070), Manegold z Lautenbach $(\dagger$ po 1103), Bernard z Clairvaux († 1153) i Wilhelm z St. Thierry († 1148). Niemniej działalność naukowa Piotra Abelarda i Gilberta z Poitiers († 1154) utorowała droge nowej metodzie scholastycznej.

W XII wieku reforma pojawiła się także w chrześcijańskiej duchowości. Próbowano w niej zbudować nowy i ściślejszy pomost oparty na bezpośredniej zależności człowieka od Boga, zwłaszcza Chrystusa-człowieka, aby w ten sposób poniżonej ludzkości dać lepsze szanse odkupienia ${ }^{76}$.

Z działających w XII wieku szkół wypada nieco więcej uwagi poświęcić szkole w Chartres, w której najjaskrawiej ujawnily się tendencje epoki. O ile początkowo uczono w niej tylko śpiewu, gramatyki i elementarnych rachunków, o tyle już połowie IX wieku doszła nauka medycyny i poezji, lektura niektórych pism patrystycznych i egzegeza biblijna ${ }^{77}$. Znaczenie szkoły w Chartres zaczęło jeszcze bardziej wzrastać od 1004 roku, gdy scholastykiem został Fulbert (ok. 970-1028), który był uczniem Gerberta z Aurillac ${ }^{78}$, późniejszego papieża Sylwestra II. Fulbert wprowadził nowy program nauczania. Poza retoryką i poezją Juwenalisa, Wergiliusza, Horacego, Stacjusza, Terencjusza i Lukiana zasadzał się on na tzw. starej logice (ars vetus), opartej na takich dziełach jak Isagoga Porfiriusza w przekładzie Wiktoryna i Boecjusza, Kategoriach Arystotelesa, Topikach Cycerona, komentarzu Boecjusza do tego dzieła i na jego traktatach $O$ sylogizmach hipotetycznych $i$ kategorycznych i $O$ podziale ${ }^{79}$. Teodoryk z Chartres ( $\left.\uparrow 1156\right)$, chociaż był najwybitniejszym platonikiem tego czasu, jako pierwszy znał już Arystotelesowskie Analityki pierwsze, Analityki wtóre i $O$ dowodach sofistycznych, które to dzieła wchodziły w zakres tzw. logiki nowej i zawierały teorię wnioskowania sylogistycznego i demonstratywnego. W późniejszym czasie uwzględniono jeszcze nauki wchodzące w skład quadrivium. Przez wprowadzenie wspomnianych trakatatów logicznych pojawiła się arystotelesowsko-boecjańska metoda badań naukowych. Znalazła ona swoje odzwierciedlenie w racjonalnej egzegezie Pisma $s w$. Do najwybiniejszych przedstawicieli szkoły w Chartres w XII wieku zaliczyć trzeba Wilhelma z Conches ${ }^{80}$, Teodoryka $\mathrm{z}$ Chartres, Gilberta de la Porrée. Dzięki ich działalności naukowej szkoła ta w pierwszej połowie tego stulecia przeżywała nawet „złoty okres" swojego rozwoju. Charakteryzował się on zwrotem do literatury antycznej, przez dogłębniejsze studium fragmentów $T i$ -

${ }^{76} \mathrm{G}$. C o n st abl e, The Reformation of the Twelfth Century, New York 1997, s. 326.

${ }_{77}$ A. C l e rva 1, Les Écoles de Chartres au moyen âge (du V au XVI siècle), Frankfurt am Main ${ }^{2}$ 1965, s. 1-28.

${ }^{78}$ Gerbert z Aurillac dzielił się ze swoimi wiadomościami z Ottonem III. U. Lindgren, Gerbert von Aurillac und das Quadrivium. Untersuchungen zur Bildung im Zeitalter der Ottonen, Wiesbaden 1976, s. $80 \mathrm{n}$.

${ }^{79}$ A. K i j ew sk a, Księga pisma i księga natury..., s. 151.

${ }^{80} \mathrm{~L}$. $\mathrm{N}$ a u ta, The 'Glosa' as Instrument for the Development of Natural Philosophy. William of Conches' Commentary on Boethius, [w:] Boethius in the Middle Ages. Latin and Vernacular Traditions of the "Consolatio philosophiae», M. J. F. M. Hoenen, L. Nauta (wyd.), Leiden-New York-Köln 1997, s. 3-39. 
maiosa odżyciem platonizmu w ujęciu Boecjusza, które to fragmenty od 1000 roku były mało studiowane, przez swoisty racjonalizm i metodologiczny naturalizm (rationes naturales) ${ }^{81}$. Tendencje te znalazły swój wyraz w teorii na$\mathrm{uki}^{82} \mathrm{i}$ prowadzily do innych badań struktury bytu materialnego ${ }^{83}$ i nowego odkrycia natury $^{84}$. Utożsamiane do tej pory z filozofią nauki wyzwolone stały się odtąd narzędziem filozofowania prowadzącym do wyjaśniania (trivium) i do zrozumienia (quadrivium) ${ }^{85}$. Pojęta jako mądrość filozofia prowadzi do zrozumienia prawdy o niebie i świecie i łączy się z przybierającą formę nauki teologia.

Myślenie wczesnośredniowieczne ksztaltował wielki autorytet św. Augustyna, sławnego oratora, literata i wiekiego myśliciela. Panujący w tym czasie a u g u s t y $\mathrm{n}$ i z m zawierał sporo elementów platonizmu i neoplatonizmu. Nie był ich pozbawiony również b o e c j a $\mathrm{n}$ i z m, w którym występowały poza neoplatonizmem już elementy arystotelizmu i który największe triumfy swojej popularności święcił w XII stuleciu. Tym idealistycznym prądom myślowym przeciwstawił się dopiero w XIII wieku realizm arystotelesowski. W miarę rozkwitu filozofii na znaczeniu traciły nauki wyzwolone, które zepchnięto do roli narzędzia filozofowania. Stawiano nawet retoryczne pytanie: Quid dant artes nisi luctum ${ }^{86}$. Jako dziedzictwo tradycyjnej retoryki pozostała teoria wymowy, co widać najbardziej w kaznodziejstwie (ars praedicandi), nauka pisania wierszy (ars poetriae, ars versificatoria), stylistyka (ars grammatica) ${ }^{87}$ i umiejętność pisania aktów urzędowych (ars dictaminis) ${ }^{88}$. Od filozofii jeszcze bardziej wzrosła ranga prawa i medycyny, jakoże przynosiły one i dochody, i uznanie w oczach społeczeństwa: Dat Galienus opes et sanctio Justiniana ${ }^{89}$

Jak powyższych wywodów widać, to mimo poważnego upadku duchowego w okresie pomiędzy patrystyką a XII wiekiem na Zachodzie pojawiły sie pierwociny nauczania chrześcijańskiego. Pierwsze szkoły powstały wokół klasztorów i katedr. Te pierwsze odegrały znacząca role w uratowaniu starożytnego dziedzictwa kulturalnego. Jedne i drugie przyczyniły sie do wprowadzenia myśli chrześcijańskiej i podniesienia poziomu wykształcenia duchowieństwa. Wczesnośredniowieczne szkolnictwo zaczęło tracić na znaczeniu

${ }^{81}$ Z. L i a n a, Koncepcja Logosu $i$ natury $w$ szkole $w$ Chartres. Heurystyczne funkcje chrześcijańskiej koncepcji Logosu w kształtowaniu się nowożytnego pojęcia natury. Analiza dorobku Szkoły w Chartres w perspektywie filozofii nauki, Kraków 1996, s. 167-232.

${ }^{82} \mathrm{~S}$. B a f i a, Teoria nauki w pismach Teodoryka i jego szkoty, ", Analecta Cracoviensia" XXI-XXII (1989/90), s. 9-28.

${ }^{83}$ Tenże, Nauka o strukturze bytu materialnego, jego przyczynach i stworzeniu świata w pismach Teodoryka $z$ Chartres, „Studia Philosophiae Christianae” 24, 2 (1988), s. 7-41.

${ }^{84}$ A. S p e e r, Die entdeckte Natur. Untersuchungen zu Begrüdungsversuchen einer "scientia naturalis “ im 12. Jahrhundert, Leiden-New York-Köln 1995.

${ }^{85}$ A. K i j e w s k a, Ksiega pisma i ksiega natury..., s. 177.

${ }^{86}$ R. K ö h n, Schulbildung..., s. 203.

${ }^{87}$ F.-H. R o b in g, Ars, kol. 1023-1024.

${ }^{88}$ M. C a m a r g o, Ars dictandi, dictaminis, [w:] Historisches Wörterbuch der Rhetorik. t. 1: $A-B i b$, kol. $1040-1046$.

${ }^{89}$ R. K ö h n, Schulbildung..., s. 203. 
dopiero wtedy, gdy zaczęły rozwijać się miasta. Z biegiem czasu w nich rozwinęło się nie tylko rzemiosło, lecz także szkolnictwo, które do końca XII wieku było w zasadzie oparte na augustyńskim ideale nauczania biblijnego wspieranego dodatkowo przez umiejętności wyzwolone.

Po okresie długiego zastoju w rozwoju szkolnictwa i nauki odrodzenie karolińskie przez zwrócenie szczególnej uwagi na ustawodawstwo szkolne otwarło nowe horyzonty dla średniowiecza. Przyczyniło się do odnowienia szkół katedralnych i parafialnych. Przy klasztorach utworzono szkoły dla świeckich ludzi. Nawet pałac królewski stał się centralnym ośrodkiem studiów. W nauczaniu szkolnym w okresie karolińskim szczególną uwagę zwrócono na tekst. W związku $\mathrm{z}$ tym zaczęły powstawać skryptoria, $\mathrm{w}$ których profesojonalnie zajmowano się przepisywaniem najlepszych tekstów.

Kolejny renesans, który nastąpił w XII wieku, był jednym z największych przełomów. Rozbudził bowiem zachwyt nie tylko dla kultury antycznej, lecz także przyczynił się do zastosowania gramatyki, retoryki, dialektyki i matematyki do lepszego poznania nauki objawionej, do dogłębniejszego zajęcia się prawem rzymskim jeszcze w tym stuleciu w Bolonii i do wprowadzenia metody arystotelesowsko-boecjańskiej, co w jakiejś mierze ułatwiło recepcję nacechowanej racjonalizmem filozofii arystotelesowskiej na Uniwersytecie Paryskim w następnym wieku. W pierwszej połowie XII wieku ważną rolę odegrała katedralna szkoła w Chartres, w której pojawiły się nowe tendencje metodologiczne zmierzające do nowego odkrycia natury. Od dwunastowiecznego renesansu średniowiecznego będzie się różnił renesans antycznej literatury i poezji XV wieku. O ile pierwszy w jakimś stopniu przygotował scholastykę, o tyle drugi programowo dążył do jej bezwzględnej krytyki i do oderwania się od myśli średniowiecznej i do wydobicia starożytnej literatury i poezji i podziwu dla antycznej kultury. Na przełomie XII i XIII wieku rozpadł się wczesnośredniowieczny system nauczania. Po wpływem recepcji pism Arystotelesa wytworzył się nowy ideał średniowiecznego szkolnego nauczania, zwanego scholastyka. Doktryna święta (doctrina sacra) pozostała wprawdzie nadal najwyższym celem wszelkiego wykształcenia i aspiracji naukowych, ale filozofia określona jako ars artium et disciplina disciplinarum wyszła poza ramy septem artes liberales po stopniowej recepcji pism Arystotelesa. Kres takiemu rozumieniu filozofii położył Tomasz z Akwinu, który wyraził się, że siedem nauk wyzwolonych nie wystarczająco dzieli filozofię teoretyczna (Septem artes liberales non sufficienter dividunt philosophiam theoreticam) ${ }^{90}$.

${ }^{90}$ Tomasz z A kw in u, In Boethium "De Trinitate», qu. 5, art. 1, ad 3. 